\title{
An Electrochemiluminescence Biosensor for the Determination of Mercury Ion via Dual-Amplification Strategy
}

\author{
Xuemei Fan, ${ }^{\oplus a, b}$ Shumin Wang, ${ }^{(*, a}$ Zhejian Li, ${ }^{\oplus *, a}$ Yimeng Wang, ${ }^{a}$ Xinhui Fan ${ }^{a, b}$ and \\ Lingmin $Y u^{b}$ \\ ${ }^{a}$ College of Chemical Engineering and Modern Materials, Shangluo University, 726000 Shangluo, P. R. China \\ ${ }^{b}$ School of Materials and Chemical Engineering, Xi'an Technological University, 710021 Xi'an, P. R. China
}

\begin{abstract}
A novel dual-signal amplificatory electrochemiluminescence (ECL) deoxyribonucleic acid (DNA) biosensor was designed for the determination of $\mathrm{Hg}^{2+}$. One amplification unit was gold nanoparticles (AuNPs) modified on a glassy carbon electrode, and the other was single-stranded DNA (ssDNA) (with amino at the 3' terminal and thiol at the 5' terminal) labeled with a carboxylfunctionalized $\mathrm{Ru} @ \mathrm{SiO}_{2}$ nanoparticles $\left(\mathrm{Ru}_{1} @ \mathrm{SiO}_{2}\right)$ as a nanoprobe. The ECL biosensor was obtained through a strong gold-sulfur bond between Au on AuNPs modified electrode and thiol in the nanoprobe. In the presence of $\mathrm{Hg}^{2+}$, the ECL signal reduced because the $\mathrm{T}-\mathrm{Hg}^{2+}$ - $\mathrm{T}$ existed between the ECL nanoprobe and the complementary DNA (c-DNA), which exhibited a sensing platform for the detection of $\mathrm{Hg}^{2+}$. The results revealed that the reduced ECL intensity was linearly proportional to the logarithm of the $\mathrm{Hg}^{2+}$ concentration in the range of $1.0 \mathrm{pmol} \mathrm{L}^{-1}-100 \mathrm{nmol} \mathrm{L}^{-1}$ with limit of detection $0.02 \mathrm{pmol} \mathrm{L}^{-1}$. The proposed method was applied for the analysis of $\mathrm{Hg}^{2+}$ in the river water and the results were in good agreement with that obtained by atomic fluorescence spectroscopy.
\end{abstract} $\mathrm{Hg}^{2+}$

Keywords: electrochemiluminescence, $\mathrm{Ru}_{1} @ \mathrm{SiO}_{2}$ nanoparticles, dual-amplification strategy,

\section{Introduction}

Mercury is one of the most toxic metal pollutants in our environment. It can accumulate in ecosystems through biological cycles ${ }^{1}$ and pose serious problems to the immune system, nervous system, cardiovascular system and reproductive system. ${ }^{2}$ Thus, the highly sensitive and selective determination of $\mathrm{Hg}^{2+}$ is increasingly important in the human health research.

The most traditional methods for $\mathrm{Hg}^{2+}$ detection can be realized by atomic absorption, atomic emission or atomic fluorescence spectrometry. Although these methods are highly sensitive, most of them require complex sample preparation and expensive instrumentation. Therefore, it is still necessary to study methods for $\mathrm{Hg}^{2+}$ detection with high specificity and sensitivity.

Biosensor is a kind of analytical device that converts biological signals combined with recognition molecules and target analytes into detectable signals, which is widely used in life analysis and environmental detection. It has

*e-mail: happywshm@126.com; Zhejian2621@163.com been demonstrated that $\mathrm{Hg}^{2+}$ can specifically interact with the thymine-thymine (T-T) mismatch in deoxyribonucleic acid (DNA) duplexes to form a T- $\mathrm{Hg}^{2+}-\mathrm{T}$ complex. ${ }^{3}$ When other metal ions, such as $\mathrm{Pb}^{2+}, \mathrm{Cu}^{2+}, \mathrm{Ni}^{2+}, \mathrm{Cd}^{2+}, \mathrm{Fe}^{2+}, \mathrm{Co}^{2+}$, $\mathrm{Zn}^{2+}$ and $\mathrm{Ca}^{2+}$ are present, the stability of the $\mathrm{T}-\mathrm{Hg}^{2+}-\mathrm{T}$ DNA duplex is not significantly affected. ${ }^{4}$ Based on this property of T-rich DNA sequences, $\mathrm{T}-\mathrm{Hg}^{2+}-\mathrm{T}$ coordination chemistry has received extensive attention in the development of $\mathrm{Hg}^{2+}$ biosensors, using colorimetry, ${ }^{5-8}$ fluorescence ${ }^{9-12}$ and electrochemistry, ${ }^{13-16}$ because T-T coordination has excellent selectivity to $\mathrm{Hg}^{2+}$.

Electrochemiluminescence (ECL) technology has received extensive attention for its simple instrumentation, high sensitivity, low background, and controllability of ECL reaction, and has a great application in biosensor detection. More recently, a series of ECL biosensors based on the specific binding of $\mathrm{T}-\mathrm{Hg}^{2+}-\mathrm{T}$ principle have been used for the detection of $\mathrm{Hg}^{2+} \cdot{ }^{17-24}$ With the development of nanotechnology, some nanomaterials, such as nano- $\mathrm{TiO}_{2},{ }^{25}$ nano- $\mathrm{Sm}_{2} \mathrm{O}_{3},{ }^{26}$ polypyrrole-cerium oxide nanocomposite ${ }^{27}$ and silver nanoparticle-decorated graphene $\operatorname{dot}^{28}$ were used to improve the ECL probe sensitivity for its excellent optical 
and electrochemical properties. Silica nanoparticles, with a unique pore structure and good biocompatibility, have been proved to be a favorable matrix to fix high concentration of Ru(bpy) ${ }_{3}{ }^{2+}$ (bpy = 2,2' -bipyridyl) and used as amplified ECL signal probe, which has realized the supersensitive analysis of nucleic acids, ${ }^{29}$ proteins, ${ }^{30}$ and cells. ${ }^{31}$ Gold nanoparticles (AuNPs) have also been widely utilized in ECL biosensors as signal-amplifying substances ${ }^{32,33}$ and carriers of proteins, such as enzymes and antibodies. ${ }^{34,35} \mathrm{Up}$ to now, no ECL biosensors have been fabricated for $\mathrm{Hg}^{2+}$ based on $\mathrm{Ru}_{1} @ \mathrm{SiO}_{2}$ nanoparticles as signal amplifying substance.

In this work, an ECL biosensor for $\mathrm{Hg}^{2+}$ was designed and implemented by integrating a carboxyl-functionalized $\mathrm{Ru} @ \mathrm{SiO}_{2}$ nanoparticles $\left(\mathrm{Ru}_{1} @ \mathrm{SiO}_{2}\right)$-tagged singlestranded DNA (ssDNA) as an ECL nanoprobe. The ECL biosensor was obtained through a strong gold-sulfur bond between Au on a AuNPs-modified glassy carbon electrode and thiol in the nanoprobe. When $\mathrm{Hg}^{2+}$ was present, retained the $\mathrm{T}$ rich oligonucleotides (complementary DNA, c-DNA), the $\mathrm{T}-\mathrm{Hg}^{2+}-\mathrm{T}$ hairpin structure was formed and this conformational resulted in the remarkable quencher of the ECL signal. So, the expression of $\mathrm{Hg}^{2+}$ could be evaluated by the reduced ECL signal (Figure 1). AuNPs in this work can be used for two purposes, one was to immobilize more ECL nanoprobe, and the other was to amplify the ECL signals. Meanwhile, $\mathrm{Ru}_{1} @ \mathrm{SiO}_{2}$ nanoparticles were chosen instead of $\mathrm{Ru}(\mathrm{bpy})_{3}$, as $\mathrm{Ru}_{1} @ \mathrm{SiO}_{2}$ nanoparticles can greatly improve the detection sensitivity for $\mathrm{Hg}^{2+}$.

\section{Experimental}

\section{Reagents}

Tris-(2,2'-bipyridyl)-dichlororuthenium(II) hexahydrate $\left(\mathrm{Ru}(\mathrm{bpy})_{3} \mathrm{Cl}_{2} \cdot 6 \mathrm{H}_{2} \mathrm{O}\right)$, tripropylamine (TPA),
N-1-(3-dimethylaminopropyl)-3-ethylcarbodiimide (EDC), hydroxysuccinimide (NHS), tetraethoxysilane (TEOS), vinyltriethoxysilane (VTES), Nafion, Triton $\mathrm{X}-100$ and $\mathrm{HgCl}_{2}$ were obtained from Sigma-Aldrich (St. Louis, Missouri, USA). Sodium citrate, chloroauric acid, cyclohexane, $n$-hexanol, acetone, ethanol, potassium ferricyanide and potassium ferrocyanide were obtained from Xi' an Chemical Reagent Company (Xi'an, China). $0.1 \mathrm{~mol} \mathrm{~L}^{-1}$ phosphate buffer saline (PBS, $0.1 \mathrm{~mol} \mathrm{~L}^{-1}$ $\mathrm{KH}_{2} \mathrm{PO}_{4} / \mathrm{K}_{2} \mathrm{HPO}_{4}-0.1 \mathrm{~mol} \mathrm{~L}^{-1} \mathrm{KCl}$, $\mathrm{pH} 7.0$ ) was used as washing solution. All aqueous solutions were prepared with ultrapure water (>18.2 M $\Omega \mathrm{cm}$ ) supplied by a Milli-Q Lab system. The $\mathrm{Hg}^{2+}$ specific oligonucleotide ${ }^{15}$ was synthesized by Shanghai Sangon Biotechnology Co. Ltd. (Shanghai, China). The sequences were as following: ssDNA: 5' -SH- $\left(-\mathrm{CH}_{2}\right)_{6}$-TTGCTCTCTCGTT- $\left(-\mathrm{CH}_{2}\right)_{6}-\mathrm{NH}_{2}-3$ ', c-DNA: 5'-TTCGTGTGTGCTT-3'.

\section{Apparatus}

MPI-E ECL analyzer (Xi'an Remax Electronics, Xi'an, China), UV-1600PC spectrophotometer (Meipuda Instruments Co., Shanghai, China), F-4600 spectrofluorometer (Hitachi, Japan), 2100F transmission electron microscopy (Electronics Corporation, Tokyo, Japan). The three-electrode system included glassy carbon electrode (GCE, $3 \mathrm{~mm}$ ) as the working electrode, $\mathrm{Ag} / \mathrm{AgCl}$ (saturated $\mathrm{KCl}$ ) as the reference electrode, platinum sheet as the counter electrode.

\section{AuNPs preparation}

AuNPs were prepared in accordance with previously described methods. ${ }^{36}$ First, $100 \mathrm{~mL}$ of $0.01 \% \mathrm{HAuCl}_{4}$ was added to a conical flask, stirred, and heated to boiling. Second, $2.75 \mathrm{~mL}$ of $1 \%$ sodium citrate solution was

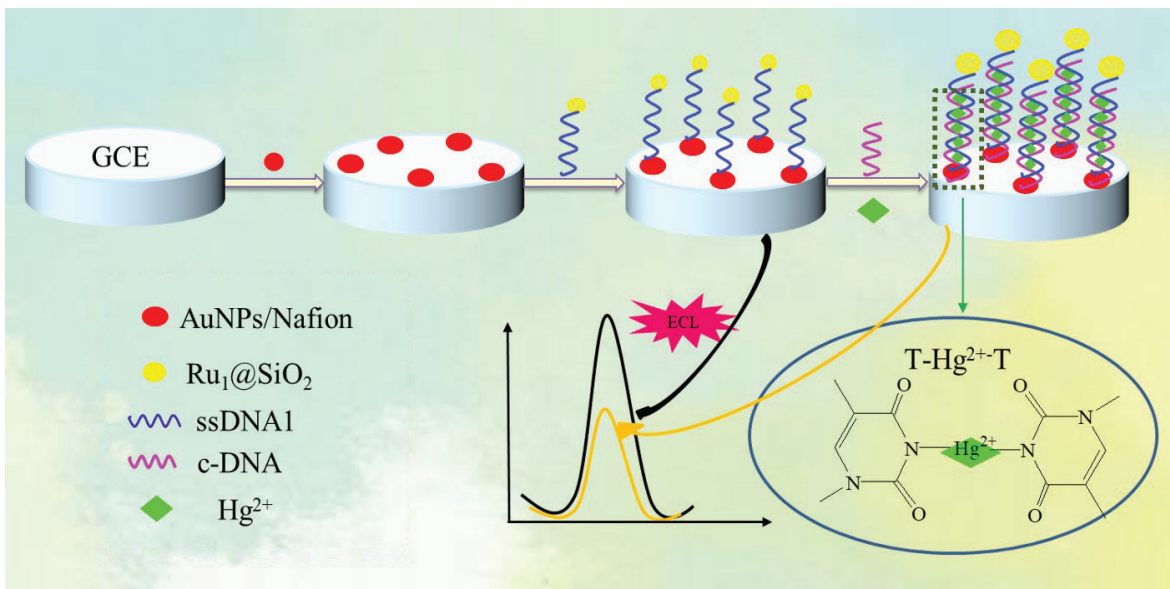

Figure 1. The principle diagram of ECL biosensor for $\mathrm{Hg}^{2+}$. 
introduced, and the solution was continuously stirred and boiled for $12 \mathrm{~min}$. The color of the solution changed from fuchsia to wine red. Heating was stopped, and the solution was naturally cooled to room temperature. Then, the solution was stored in a brown bottle at $4{ }^{\circ} \mathrm{C}$.

\section{$\mathrm{Ru}_{1} @ \mathrm{SiO}_{2}$ nanoparticles preparation}

The $\mathrm{Ru}_{1} @ \mathrm{SiO}_{2}$ nanoparticles were prepared according to the literature reported before. ${ }^{37}$ Firstly, cyclohexane, Triton $\mathrm{x}-100$ and 1-hexanol were mixed at a volume ratio of $4.2: 1: 1$, together with $500 \mu \mathrm{L}$ of ultrapure water, stirred for $30 \mathrm{~min}$. Then, $50 \mu \mathrm{L}$ of $0.01 \mathrm{~mol} \mathrm{~L}^{-1} \mathrm{Ru}(\mathrm{bpy})_{3}{ }^{2+}$ was added, and the $\mathrm{pH}$ of the solution was adjusted to neutral with $\mathrm{NaOH}$. The solution was concurrently stirred for $1 \mathrm{~h}$. Subsequently, polymerization was initiated, and hydrolysis was allowed by adding $90 \mu \mathrm{L}$ of TEOS and $60 \mu \mathrm{L}$ of $\mathrm{NH}_{4} \mathrm{OH}$. This process was continued for $24 \mathrm{~h}$. Lastly, emulsion was destroyed with acetone and centrifuged three times with ethanol and water to obtain the orange $\mathrm{Ru} @ \mathrm{SiO}_{2}$ nanoparticles.

$\mathrm{Ru} @ \mathrm{SiO}_{2}$ nanoparticles were dispersed in $1.0 \mathrm{~mL}$ of ethanol solution, mixed with $500 \mu \mathrm{L}$ of VTES, and reacted under continuous stirring for $12 \mathrm{~h}$. The received solution was dispersed in a mixture of $4.2 \mathrm{mg} \mathrm{mL}^{-1} \mathrm{NaIO}_{4}$ and $0.1 \mathrm{mg} \mathrm{mL}^{-1} \mathrm{KMnO}_{4}$ for $5 \mathrm{~h}$. Lastly, the $\mathrm{Ru}_{1} @ \mathrm{SiO}_{2}$ nanoparticles were obtained.

\section{ECL nanoprobe preparation}

$\mathrm{Ru}_{1} @ \mathrm{SiO}_{2}$-ssDNA as an ECL probe was synthesized in accordance with a previously described method with some modifications. ${ }^{38}$ Firstly, a newly prepared mixed solution containing $5 \mathrm{mg} \mathrm{mL}^{-1} \mathrm{NHS}$ and $2 \mathrm{mg} \mathrm{mL}^{-1} \mathrm{EDC}$ was added to the $\mathrm{Ru}_{1} @ \mathrm{SiO}_{2}$ nanoparticles to activate the carboxyl groups in $\mathrm{Ru}_{1} @ \mathrm{SiO}_{2}$ for 30 min. Secondly, the amino and thiol-binding ssDNA solution, which was prepared by dissolving $2.0 \mathrm{OD}$ (optical density, about $66 \mu \mathrm{g}$ ) of ssDNA in $1.0 \mathrm{~mL}$ of $0.1 \mathrm{~mol} \mathrm{~L}^{-1} \mathrm{PBS}$ ( $\mathrm{pH} 7.0$ ), was added and shaken at low speed for $24 \mathrm{~h}$ at room temperature. Then, $200 \mu \mathrm{L}$ of $1.5 \mathrm{~mol} \mathrm{~L}^{-1} \mathrm{NaAc}$ and $1.0 \mathrm{~mL}$ ethanol were added to the mixture above and reacted for $12 \mathrm{~h}$ at $-20^{\circ} \mathrm{C}$ in a refrigerator. Finally, the mixture was centrifuged for $30 \mathrm{~min}$ at $12000 \mathrm{r} \mathrm{min}^{-1}$ using a micro-centrifuge and the precipitate were rinsed with ethanol for three times. The dried precipitate was dissolved in $500 \mu \mathrm{L}$ of $0.1 \mathrm{~mol} \mathrm{~L}^{-1}$ PBS (pH 7.0) and stored at $-18{ }^{\circ} \mathrm{C}$ in refrigerator.

\section{Preparation of the ECL biosensor}

Before modification, the bare GCE was polished to a mirror-like surface with $0.3-0.05 \mu \mathrm{m}$ alumina powder and thoroughly cleaned ultrasonically with ethanol and ultrapure water. Then, $0.5 \%$ Nafion solution and AuNP solution were mixed at a volume ratio of $1: 2$, and the mixture was ultrasonicated for $30 \mathrm{~min}$. Afterward, $10 \mu \mathrm{L}$ of the mixture solution (AuNPs with Nafion) was drop onto the surface of the pretreated GCE to form a AuNP/Nafion film-modified GCE. After the specimen was washed with water, the modified electrode was immersed in $200 \mu \mathrm{L}$ of $1.7 \mu \mathrm{mol} \mathrm{L} \mathrm{L}^{-1} \mathrm{ECL}$ nanoprobe for $90 \mathrm{~min}$ and washed with the washing buffer.

\section{ECL measurements}

The prepared ECL biosensor was immersed in $200 \mu \mathrm{L}$ of different $\mathrm{Hg}^{2+}$ concentrations including $0.8 \mu \mathrm{mol} \mathrm{L}^{-1}$ of c-DNA for $70 \mathrm{~min}$, washed with the washing buffer, and dried in air. The ECL signal was detected in $2.0 \mathrm{~mL}$ of $50 \mathrm{mmol} \mathrm{L}^{-1} \mathrm{TPA}\left(0.1 \mathrm{~mol} \mathrm{~L}^{-1} \mathrm{PBS}, \mathrm{pH}=7.0\right)$ at a constant potential of $+1.28 \mathrm{~V}$. The $\mathrm{Hg}^{2+}$ concentration was quantified in terms of a decrease in the ECL intensity by using the following formula: $\Delta \mathrm{I}_{\mathrm{ECL}}\left(\Delta \mathrm{I}_{\mathrm{ECL}}=\mathrm{I}_{0}-\mathrm{I}_{\mathrm{t}}\right)$, where $\mathrm{I}_{0}$ is the ECL intensity in the absence of $\mathrm{Hg}^{2+}$, and $\mathrm{I}_{\mathrm{t}}$ is the ECL intensity in the presence of $\mathrm{Hg}^{2+}$. All experiments were conducted at room temperature $\left(25 \pm 1{ }^{\circ} \mathrm{C}\right)$.

\section{Results and Discussion}

\section{Characterization of AuNPs}

Transmission electron microscopy was conducted to characterize the size and morphology of AuNPs before ultrasonic treatment for $5 \mathrm{~min}$. As shown in Figure 2a, the prepared AuNPs were spherical and had smooth surfaces, and their average size was about $13 \mathrm{~nm}$ in diameter. As illustrated in Figure 2b, the UV-Vis absorption spectra showed maximal absorption at $520 \mathrm{~nm}$, and the AuNP concentration estimated through UV-Vis spectroscopy was $3.5 \times 10^{-9} \mathrm{~mol} \mathrm{~L}^{-1}$ based on an extinction coefficient of $2.7 \times 10^{8} \mathrm{~mol} \mathrm{~L}^{-1} \mathrm{~cm}^{-1}$ at $\lambda=520 \mathrm{~nm}$ for $13 \mathrm{~nm}$ particles. ${ }^{36}$

\section{Characterization of ECL nanoprobe}

Figure 3A showed that the resultant $\mathrm{Ru}_{1} @ \mathrm{SiO}_{2}$ had good dispersibility and an average diameter of about $50 \mathrm{~nm}$. Figure 3B illustrated the UV-Visible spectra of $\mathrm{Ru}(\mathrm{bpy})_{3}{ }^{2+}, \mathrm{Ru}_{1} @ \mathrm{SiO}_{2}$, ssDNA, and $\mathrm{Ru}_{1} @ \mathrm{SiO}_{2}$-ssDNA. The absorption spectra of the pure $\mathrm{Ru}(\mathrm{bpy})_{3}{ }^{2+}$ (line a) and synthesized $\mathrm{Ru}_{1} @ \mathrm{SiO}_{2}$ (line b) were largely similar, and two maximum absorption peaks were found at about 290 and $458 \mathrm{~nm}$. A characteristic absorption peak at 


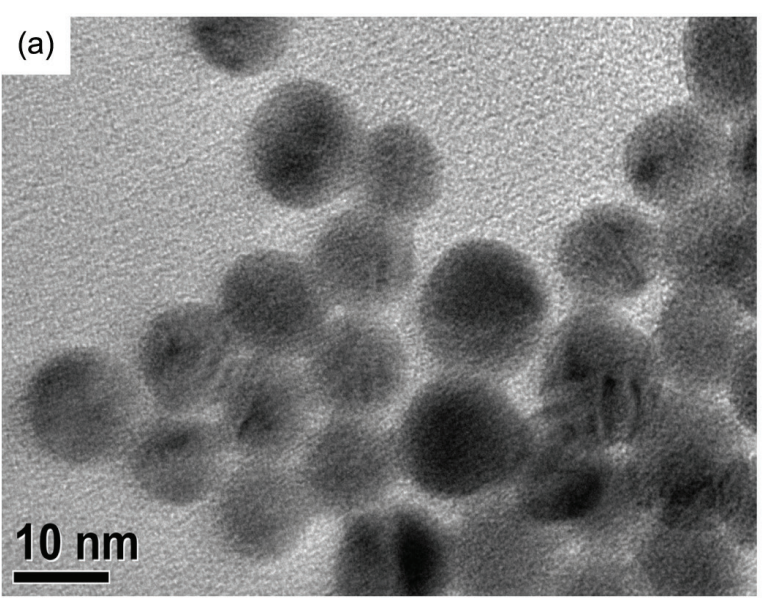

Figure 2. TEM image (a) and UV-Vis spectra (b) of AuNPs.

$260 \mathrm{~nm}$ was observed in the spectrum of ssDNA (line c). The $\mathrm{Ru}_{1} @ \mathrm{SiO}_{2}$-ssDNA showed absorption peaks at 287, 457 , and $246 \mathrm{~nm}$ (line d). In comparison with the peaks at 290 and $458 \mathrm{~nm}$ of $\mathrm{Ru}_{1} @ \mathrm{SiO}_{2}$ and at $260 \mathrm{~nm}$ of the ssDNA, a blue shift occurred, indicating that the $\mathrm{Ru}_{1} @ \mathrm{SiO}_{2}$-ssDNA was successfully synthesized. The UV-Visible absorption of $\mathrm{Ru}(\mathrm{bpy})_{3}{ }^{2+}$ at $458 \mathrm{~nm}$ indicated that the concentration of the nanoprobes was estimated to be $9.2 \times 10^{-6} \mathrm{~mol} \mathrm{~L}^{-1} .^{38}$ Figure $3 \mathrm{C}$ showed the fluorescence spectra of $\mathrm{Ru}(\mathrm{bpy})_{3}{ }^{2+}$
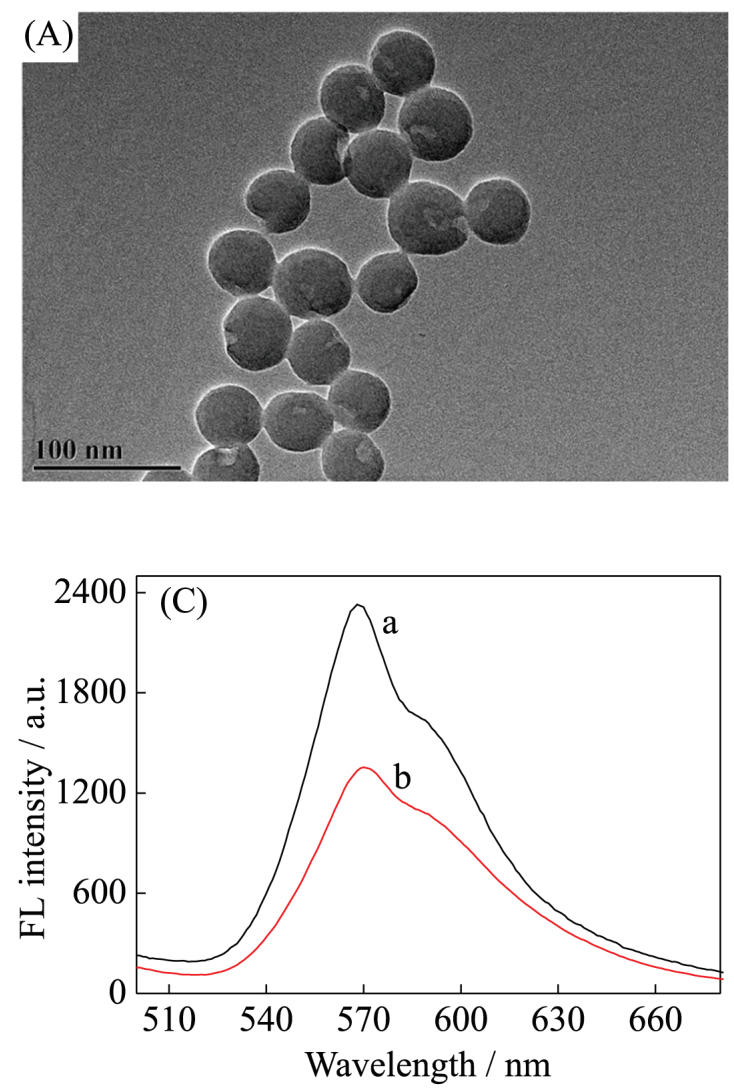

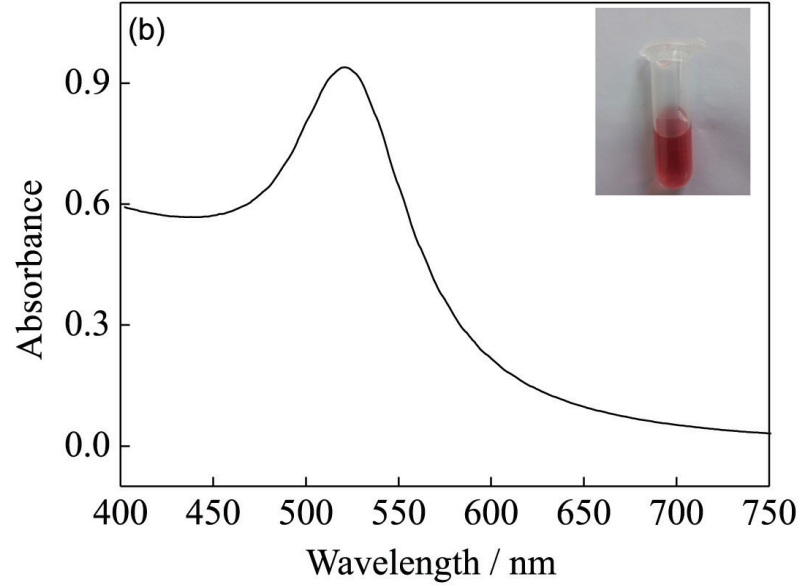

and $\mathrm{Ru}_{1} @ \mathrm{SiO}_{2}$-ssDNA, when the excitation wavelength was $458 \mathrm{~nm}$. The maximum emission wavelength of $\mathrm{Ru}(\mathrm{bpy})_{3}{ }^{2+}$ and $\mathrm{Ru}_{1} @ \mathrm{SiO}_{2}$-ssDNA was 568 and 570 nm, respectively. This indicated the success of our nanoprobe preparation. Figure 3D presented the ECL intensity-potential curves of $\mathrm{Ru}(\mathrm{bpy})_{3}{ }^{2+}$ and $\mathrm{Ru}_{1} @ \mathrm{SiO}_{2}$-ssDNA in $50 \mathrm{mmol} \mathrm{L}^{-1}$ TPA $\left(0.1 \mathrm{~mol} \mathrm{~L}^{-1} \mathrm{PBS}, \mathrm{pH}=7.0\right)$, it can be calculated that a peak ECL intensity occurred at about $1.28 \mathrm{~V}$ at $\mathrm{Ru}_{1} @ \mathrm{SiO}_{2}-\mathrm{ssDNA}$, relative to $1.25 \mathrm{~V}$ of $\mathrm{Ru}(\mathrm{bpy})_{3}{ }^{2+}$, there
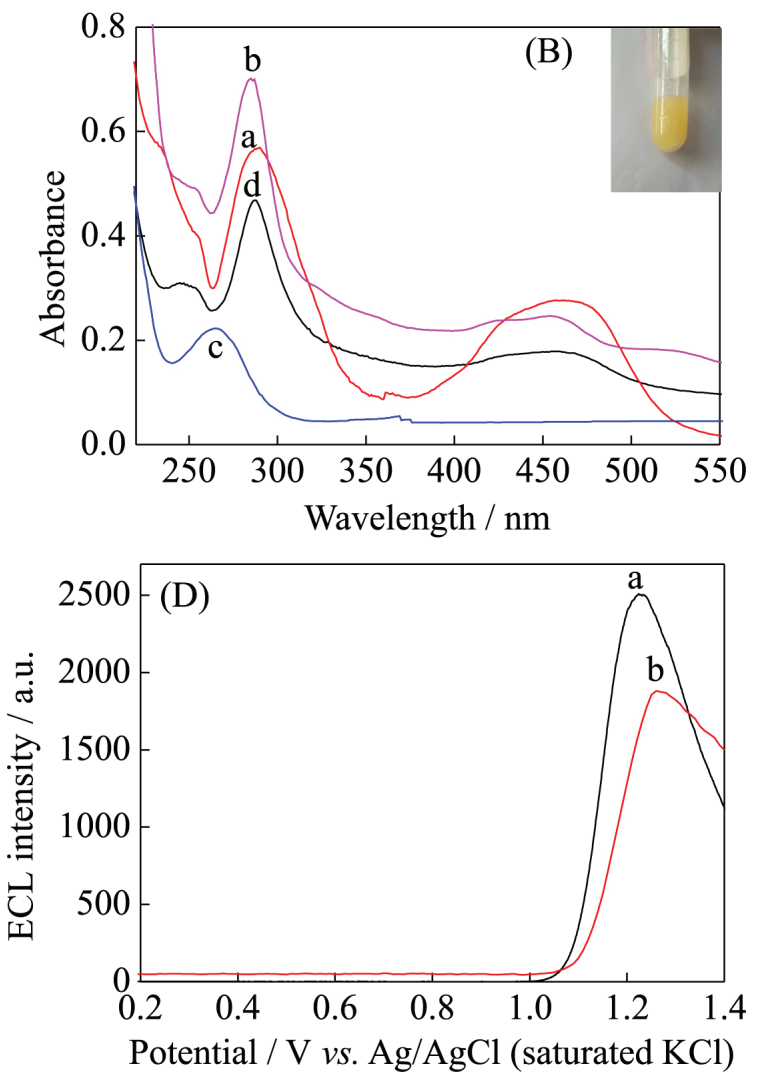

Figure 3. (A) TEM images of $\mathrm{Ru}_{1} @ \mathrm{SiO}_{2}$; (B) UV-Vis absorption spectra of $\mathrm{Ru}(\mathrm{bpy})_{3}{ }^{2+}$ (a), $\mathrm{Ru}_{1} @ \mathrm{SiO}_{2}$ (b), ssDNA (c) and $\mathrm{Ru}_{1} @ \mathrm{SiO}{ }_{2}-\mathrm{SsDNA}$ (d); (C) fluorescence spectra and (D) ECL intensity-potential profiles of Ru(bpy) ${ }_{3}^{2+}$ (a) and $\mathrm{Ru}_{1} @ \mathrm{SiO}_{2}-\mathrm{SsDNA}$ (b). 
was a little shift, this indicated that the $\mathrm{Ru}_{1} @ \mathrm{SiO}_{2}$-ssDNA could effectively do its ECL reaction, and the preparation of nanoprobe was successful.

\section{Optimization of experimental conditions}

According to the analytical principle, the experimental conditions were optimized, including the assembly time and the concentration of the ECL nanoprobe, the concentration of the c-DNA and the reaction time for $\mathrm{T}-\mathrm{Hg}^{2+}-\mathrm{T}$ interaction.

The assembly time of the ECL nanoprobe with the AuNP was investigated (Figure 4a) after interaction with 10 pmol L-1 $\mathrm{Hg}^{2+}$. We can observe that $\Delta \mathrm{I}_{\mathrm{ECL}}$ increased as the assembly time was prolonged from 50 to $90 \mathrm{~min}$. When the assembly time was further prolonged, $\Delta \mathrm{I}_{\mathrm{ECL}}$ slightly increased, indicating that the quantity of nanoprobes reached saturation. Thus, 90 min was chosen as the optimal assembly time.

Figure $4 \mathrm{~b}$ showed the effect of the concentration of the ECL nanoprobe on the ECL intensity. It can be seen that the $\Delta \mathrm{I}_{\mathrm{ECL}}$ increased with an increase of the concentration of the ECL nanoprobe from 1.0 to $1.7 \mu \mathrm{mol} \mathrm{L}^{-1}$ and then reached a plateau at $1.7 \mu \mathrm{mol} \mathrm{L} \mathrm{L}^{-1}$, which indicated that it was sufficient in the tested case. Therefore, $1.7 \mu \mathrm{mol} \mathrm{L}{ }^{-1}$ ECL probe was employed in following experiments.
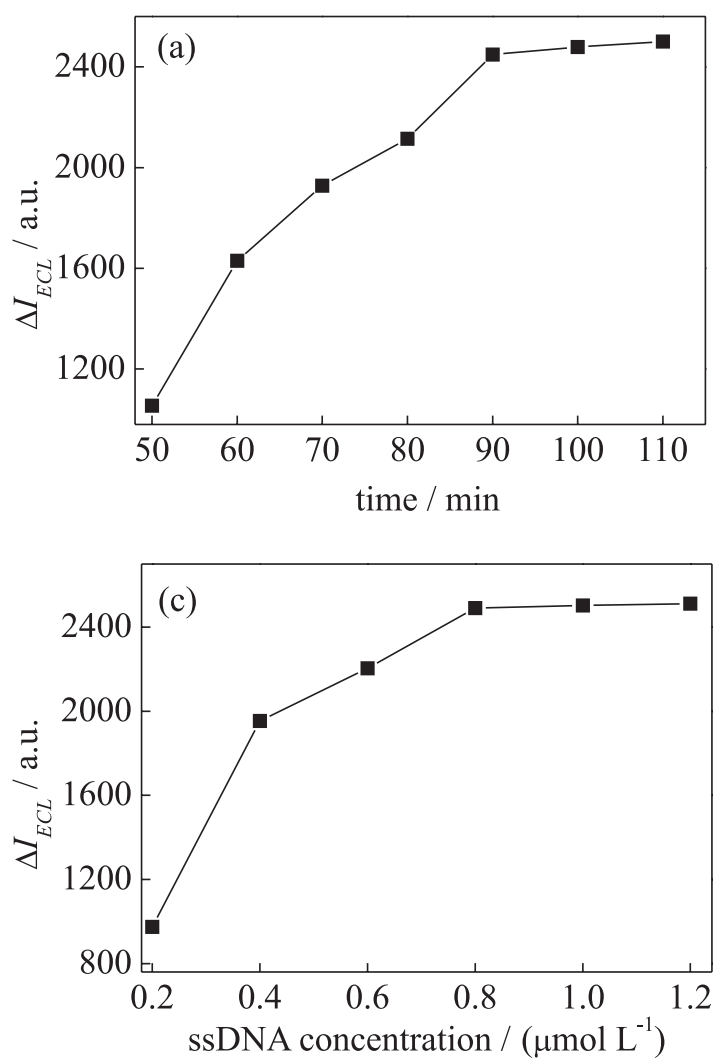

Figure $4 \mathrm{c}$ showed the $\Delta \mathrm{I}_{\mathrm{ECL}}$ increased as the concentration of c-DNA increased from 0.2 to $0.8 \mu \mathrm{mol} \mathrm{L}{ }^{-1}$, thereafter, no obvious change has been observed in the ECL intensity after $0.8 \mu \mathrm{mol} \mathrm{L} \mathrm{L}^{-1}$. This indicates that the $\mathrm{T}-\mathrm{Hg}^{2+}-\mathrm{T}$ reaction were complete when the concentration is $0.8 \mu \mathrm{mol} \mathrm{L}{ }^{-1}$, so this concentration was chosen in the test.

As shown in Figure $4 d$, the $\Delta \mathrm{I}_{\mathrm{ECL}}$ increased dramatically with the increasing of the reaction time during the initial stages, and the increase was very slow after $50 \mathrm{~min}$. Considering the fact that the reaction time was longer when the concentration of $\mathrm{Hg}^{2+}$ was lower. So, 70 min was chosen as the optimal reaction time for $\mathrm{T}-\mathrm{Hg}^{2+}-\mathrm{T}$ interaction.

\section{Performance of the biosensor for $\mathrm{Hg}^{2+}$}

The ECL intensity was determined at different $\mathrm{Hg}^{2+}$ concentrations under the optimized conditions. $\Delta \mathrm{I}_{\mathrm{ECL}}$ increased as the $\mathrm{Hg}^{2+}$ concentration increased and was linearly proportional to the logarithm of the $\mathrm{Hg}^{2+}$ concentration with a linear range of $1.0 \mathrm{pmol} \mathrm{L}^{-1}-100 \mathrm{nmol} \mathrm{L}^{-1}$ (Figure 5). The linear regression equation was $\Delta \mathrm{I}=3876.43+704.94 \log \mathrm{C}$ ( $\mathrm{nmol} \mathrm{L} \mathrm{L}^{-1}$ ), and the regression coefficient $(\mathrm{R})$ was 0.9954 . The limit of detection was defined as $0.02 \mathrm{pmol} \mathrm{L}^{-1}$ at a signal-to-noise ratio of 3 . For comparison purposes, we summarized some biosensors previously reported for $\mathrm{Hg}^{2+}$
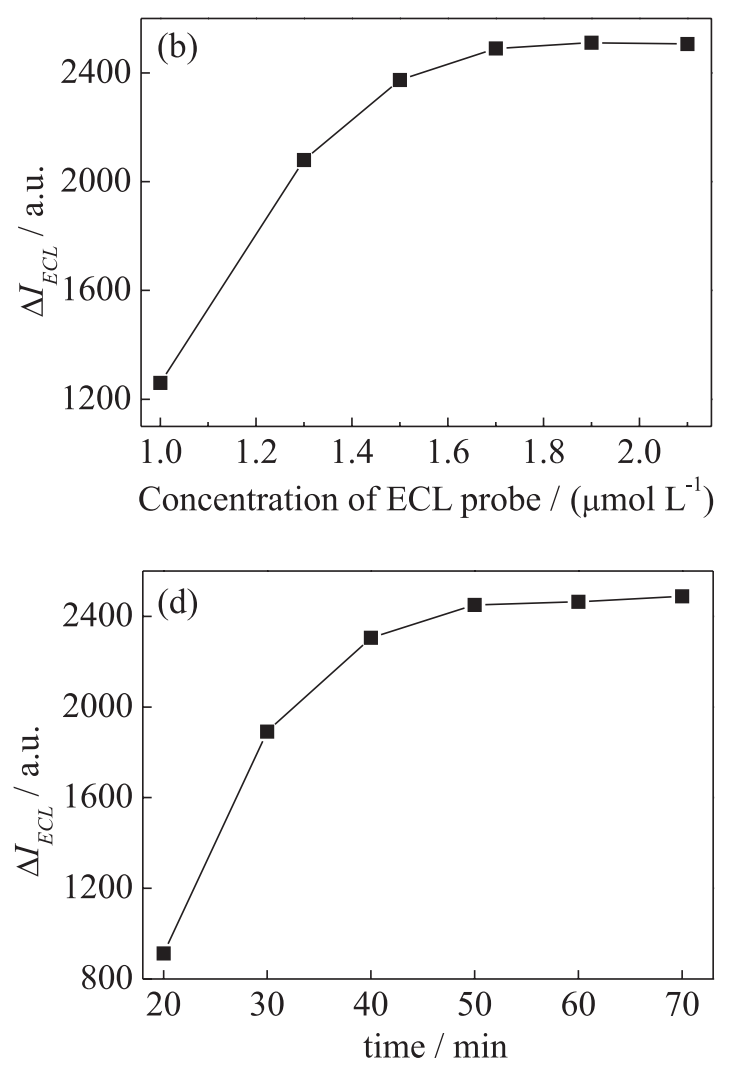

Figure 4. Effect of the assembly time (a) and concentration (b) of the ECL nanoprobe, the concentration of c-DNA (c) and the reaction time for T-Hg ${ }^{2+}-\mathrm{T}$ (d) on the ECL intensity in $50 \mathrm{mmol} \mathrm{L}^{-1} \mathrm{TPA}\left(0.1 \mathrm{~mol} \mathrm{~L}^{-1} \mathrm{PBS}, \mathrm{pH}=7.0\right) . \mathrm{Hg}^{2+}$ in pmol L-1. 
in Table 1. As shown in Table 1, the linear range of this method was wide and the limit of detection was lower than all the previous works.

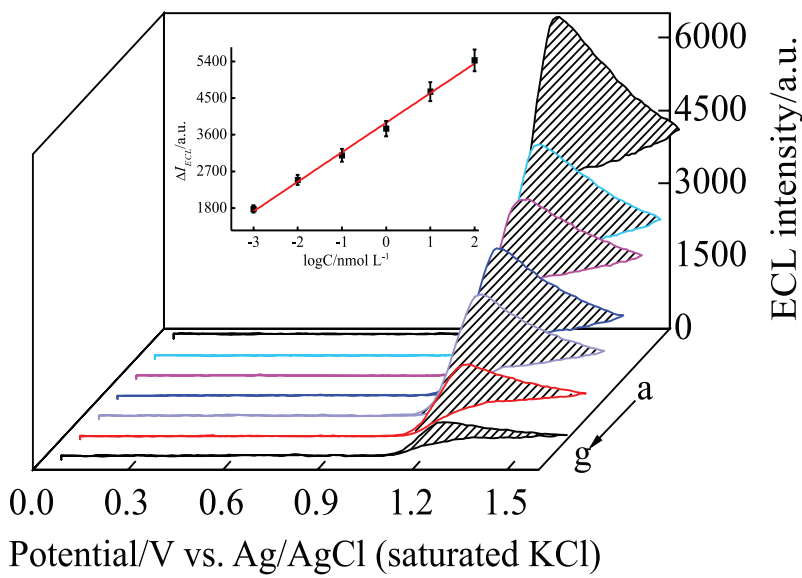

Figure 5. ECL intensity-potential curves with different concentrations of $\mathrm{Hg}^{2+}$ at $100 \mathrm{mV} \mathrm{s}^{-1}$ in $50 \mathrm{mmol} \mathrm{L}^{-1} \mathrm{TPA}\left(0.1 \mathrm{~mol} \mathrm{~L}^{-1} \mathrm{PBS}, \mathrm{pH}=7.0\right)$. (a) 0 , (b) $1.0 \mathrm{pmol} \mathrm{L}-1$, (c) $10 \mathrm{pmol} \mathrm{L}^{-1}$, (d) $100 \mathrm{pmol} \mathrm{L}^{-1}$, (e) $1 \mathrm{nmol} \mathrm{L}^{-1}$, (f) $10 \mathrm{nmol} \mathrm{L}^{-1}$, (g) $100 \mathrm{nmol} \mathrm{L}{ }^{-1}$. Inset: calibration curve for $\mathrm{Hg}^{2+}$.

Table 1. Detection for $\mathrm{Hg}^{2+}$ using different sensors

\begin{tabular}{lccc}
\hline Method & Linear range & $\begin{array}{c}\text { Limit of } \\
\text { detection }\end{array}$ & Reference \\
\hline FL & $10-600 \mathrm{nM}$ & $0.24 \mathrm{nM}$ & 9 \\
EC & $0.1-200 \mathrm{nM}$ & $0.05 \mathrm{nM}$ & 16 \\
ECL & $8 \mathrm{pM}-2 \mathrm{nM}$ & $2 \mathrm{pM}$ & 20 \\
ECL & $0.01-600 \mathrm{nM}$ & $5 \mathrm{pM}$ & 21 \\
ECL & $0.1-10 \mathrm{pM}$ & $0.04 \mathrm{pM}$ & 22 \\
This article & $1.0 \mathrm{pM}-100 \mathrm{nM}$ & $0.02 \mathrm{pM}$ & \\
\hline
\end{tabular}

FL: fluorometirc; EC: electrochemical; ECL: electrochemiluminescence.

The reproducibility of the fabricated biosensor was measured using five individual biosensors with a standard deviation of $2.9 \%$, and $3.3 \%$ for seven independent measurements using the same biosensor, take $10 \mathrm{pmol} \mathrm{L}^{-1}$ $\mathrm{Hg}^{2+}$ as a model. These results indicated that the fabricated biosensors had good reproducibility.

The storage performance of the ECL biosensor was also studied. After 1 week of storage at $4{ }^{\circ} \mathrm{C}$ in $0.1 \mathrm{~mol} \mathrm{~L}^{-1} \mathrm{PBS}$
( $\mathrm{pH} 7.0)$, the average ECL value of the biosensor was $98.2 \%$

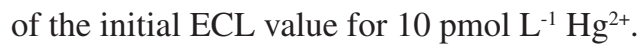

Interference experiments were conducted using $\mathrm{Ni}^{2+}$, $\mathrm{Co}^{2+}, \mathrm{Cu}^{2+}, \mathrm{Cd}^{2+}, \mathrm{Pb}^{2+}, \mathrm{Mn}^{2+}$ and $\mathrm{Zn}^{2+}$ to investigate the selectivity of the ECL biosensor (Figure 6). The results showed that $\mathrm{Hg}^{2+}$ had significant ECL strength, whereas 1000-fold of the seven other metal ions had weak emissions comparable with the blank strength. The selectivity of the biosensor was also examined in a mixture containing $\mathrm{Hg}^{2+}$ and the metal ion. The signals obtained from the mixture were similar to those obtained from the pure $\mathrm{Hg}^{2+}$ solution. These results indicated that the specificity of the biosensor for $\mathrm{Hg}^{2+}$ was high.

The application of the ECL biosensor was also investigated. Lake water samples were collected from Danjiang River in Shangluo City of China and filtered through $0.2 \mu \mathrm{m}$ membranes to remove impurities. The real sample was prepared by spiking different $\mathrm{Hg}^{2+}$ concentrations into lake water samples. The $\mathrm{Hg}^{2+}$ concentration was estimated with the proposed ECL biosensor, as well with the atomic fluorescent spectrometry (AFS). The experimental results are shown in Table 2. The RSD of each sample was less than $3.71 \%$ for five parallel detections, and recovery varied from $96.8 \%$ to $106.9 \%$. The results were in good agreement with those obtained by AFS, showing the potential practicality of the biosensor for real samples.

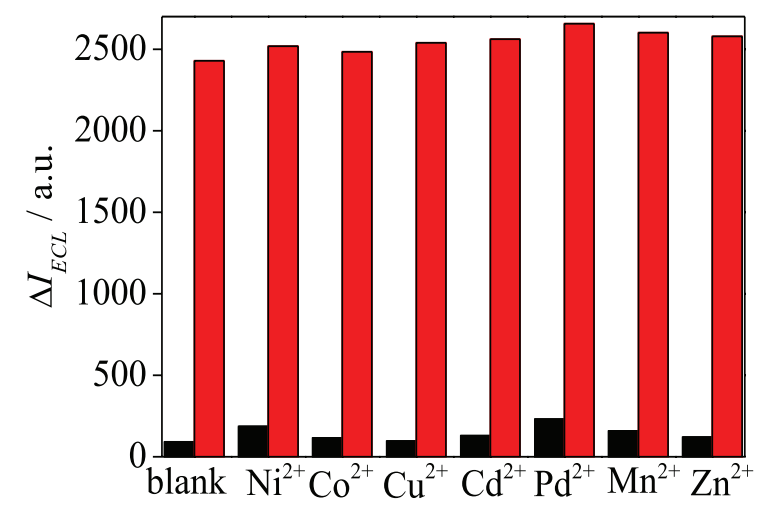

Figure 6. Selectivity of the ECL biosensor to $10 \mathrm{pmol} \mathrm{L}^{-1} \mathrm{Hg}^{2+}$ by comparing it to the interfering metal ions, $10 \mathrm{nmol} \mathrm{L}-1 \mathrm{Ni}^{2+}, \mathrm{Co}^{2+}, \mathrm{Cu}^{2+}$, $\mathrm{Cd}^{2+}, \mathrm{Pb}^{2+}, \mathrm{Mn}^{2+}$ and $\mathrm{Zn}^{2+}$. The black was individual metal ion alone and red was coexistence of $\mathrm{Hg}^{2+}$ and the metal ion.

Table 2. Recovery results of the proposed biosensors in real serum samples $(n=5)$

\begin{tabular}{lccccc}
\hline Sample number & Added / $\left(\mathrm{nmol} \mathrm{L}^{-1}\right)$ & This method / $\left(\mathrm{nmol} \mathrm{L}^{-1}\right)$ & RSD / \% & Recovery / \% & AFS / $(\mathrm{nmol} \mathrm{L})$ \\
\hline 1 & 4.00 & 3.87 & 3.52 & 96.8 & 3.92 \\
2 & 8.00 & 7.86 & 2.73 & 3.2 & 8.09 \\
3 & 12.00 & 12.83 & 3.19 & 106.9 & 12.42 \\
4 & 16.00 & 16.46 & 3.71 & 102.8 & 16.39 \\
5 & 20.00 & 19.81 & 2.93 & 99.0 & 20.13 \\
\hline
\end{tabular}

RSD: relative standard deviation; AFS: atomic fluorescent spectrometry. 


\section{Conclusions}

A novel ECL biosensor was designed through a dual-amplification strategy to detect $\mathrm{Hg}^{2+}$. The $\mathrm{Ru}_{1} @ \mathrm{SiO}_{2}$-ssDNA composite acted as an ECL nanoprobe, and AuNPs acted as nanocarriers to immobilize a large number of signal probes. Sensitivity could be further improved by employing the dual-amplification strategy.

This approach has been successfully applied to the monitoring of $\mathrm{Hg}^{2+}$ in river water samples. Furthermore, it could be extended to the development of other ECL and electrochemical biosensing methods for other metal ions.

\section{Acknowledgments}

This project was supported by the National Natural Science Foundation of China (No. 30970696), the Science and Technology Planning Project (2012KTDZ 02-02) and the Natural Science Basic Research Plan in ShaanXi Province of China (2018JM2040).

\section{Author Contributions}

Xuemei Fan was responsible for methodology; Shumin Wang for data curation; Zhejian Li for methodology; Yimeng Wang for data curation; Xinhui Fan for conceptualization and data curation and Lingmin Yu for formal analysis.

\section{References}

1. Monikh, F. A.; Karami, O.; Hosseini, M.; Karami, N.; Bastami, A. A.; Ghasemi, A. F.; Ecotoxicol. Environ. Saf. 2013, 94, 112.

2. Wang, Q.; Kim, D.; Dionysiou, D. D.; Sorial, G. A.; Timberlake, D.; Environ. Pollut. 2004, 131, 323.

3. Li, L. Y.; Wen, Y. L.; Xu, L.; Xu, Q.; Song, S. P.; Zuo, X. L.; Yan, J.; Zhang, W. J.; Liu, G.; Biosens. Bioelectron. 2016, 75, 433.

4. Miyake, Y.; Togashi, H.; Tashiro, M.; Yamaguchi, H.; Oda, S.; Kudo, M.; Tanaka, Y.; Kondo, Y.; Sawa, R.; Fujimoto, T.; Machinami, T.; Ono, A.; J. Am. Chem. Soc. 2006, 128, 2172.

5. Chen, G. H.; Chen, W. Y.; Yen, Y. C.; Wang, C. W.; Chang, H. T.; Chen, C. F.; Anal. Chem. 2014, 86, 6843.

6. Shi, X.; Gao, X.; Zhang, L.; Li, Y.; Fan, L.; Yu, H. Z.; Analyst 2015, 140, 2608.

7. Deng, P. X.; Zheng, S.; Yun, W.; Zhang, W. L.; Yang, L. Z.; Spectrochim. Acta, Part A 2019, 210, 335.

8. Yu, T.; Zhang, T. T.; Zhao, W.; Xu, J. J.; Chen, H. Y.; Talanta 2017, 165, 570.

9. Li, Z. H.; Sun, H. J.; Ma, X. Y.; Su, R. F.; Sun, R.; Yang, C. Y.; Sun, C. Y.; Anal. Chim. Acta 2020, 1099, 136.
10. Chen, T.; Tan, S.; Wei, L. I.; Anal. Sci. 2017, 33, 1333.

11. Kim, H. S.; Angupillai, S.; Jeong, Y. M.; Park, J. S.; Kim, C. H.; Son, Y. A.; Sens. Actuators, B 2017, 240, 1272.

12. Makam, P.; Shilpa, R.; Kandjani, A. E.; Periasamy, S. R.; Govindaraju, T.; Biosens. Bioelectron. 2018, 100, 556.

13. Hong, M. Q.; Wang, M. Y.; Wang, J.; Xu, X. Q.; Lin, Z. Y.; Biosens. Bioelectron. 2017, 94, 19.

14. He, L. L.; Cheng, L.; Lin, Y.; Cui, H. F.; Hong, N.; Peng, H.; Kong, D. R.; Chen, C. D.; Zhang, J.; Wei, G. B.; Fan, H.; J. Electroanal. Chem. 2018, 814, 161.

15. Xu, A.; Chao, L.; Xiao, H.; Sui, Y.; Liu, J.; Xie, Q.; Yao, S.; Biosens. Bioelectron. 2018, 104, 95.

16. Zhang, Y. Y.; Zhang, C.; Ma, R.; Du, X.; Dong, W. H.; Chen, Y.; Chen, Q.; Mater. Sci. Eng., C 2017, 75, 175.

17. Cheng, L.; Wei, B. G.; He, L. L.; Mao, L.; Zhang, J.; Ceng, J. X.; Kong, D. R.; Chen, C. D.; Cui, H. F.; Hong, N.; Fan, H.; Anal. Biochem. 2017, 518, 46.

18. Huang, Y. Z.; Li, L.; Zhang, Y.; Zhang, L. N.; Ge, S. G.; Yua, J. H.; Biosens. Bioelectron. 2019, 126, 339.

19. Li, J.; Lu, L. P.; Kang, T. F.; Cheng, S. Y.; Biosens. Bioelectron. 2016, 7715, 740.

20. Wang, D. M.; Gai, Q. Q.; Huang, R. F.; Zheng, X. W.; Biosens. Bioelectron. 2017, 98, 134.

21. Huang, R. F.; Liu, H. X.; Gai, Q. Q.; Liu, G. J.; Wei, Z.; Biosens. Bioelectron. 2015, 71, 194.

22. Ma, F.; Chen, Y.; Zhu, Y. C.; Liu, J. W.; Talanta 2019, $194,114$.

23. Babamiri, B.; Salimi, A.; Hallaj, R.; Biosens. Bioelectron. 2018 , 102, 328.

24. Tang, Y.; Li, J. J.; Guo, Q. F.; Nie, G. M.; Biosens. Bioelectron. 2019, 282, 824.

25. Ma, X. G.; Wang, C.; Wu, F. X.; Guan, Y. R.; Xu, G. B.; Top. Curr. Chem. 2020, 378, 28.

26. Mesgari, F.; Beigi, S. M.; Hosseini, F. S. M.; Ganjali, M. R.; Inorg. Chem. Commun. 2019, 106, 240.

27. Karimi, A.; Husain, S. W.; Hosseini, M.; Azar, P. A.; Ganjali, M. R.; Sens. Actuators, B 2018, 271, 90.

28. Salehnia, F.; Hosseini, M.; Ganjaliac, M. R.; Anal. Methods 2018, 10, 508.

29. Li, M.; Yang, H. M.; Yan, M. A.; Sens. Actuators, B 2014, 191, 377.

30. Chen, Z. H.; Liu, Y.; Li, J. H.; Anal. Chem. 2013, 85, 4431.

31. Huang, X.; Deng, X.; Qi, W.; Wu, D.; New J. Chem. 2018, 42, 13558.

32. Wang, X.; Wang, Y.; Jiang, M.; Shan, Y. Q.; Jin, X.; Gong, M.; Wang, X. N.; Anal. Biochem. 2018, 548, 15.

33. Jiang, W. J.; Yin, H. S.; Zhou, Y. L.; Duan, J. L.; Ai, S. Y.; Sens. Actuators, B 2018, 274, 144.

34. Cao, J. T.; Yang, J. J.; Zhao, L. Z.; Wang, Y. L.; Wang, H.; Liu, Y. M.; Ma, S. H.; Biosens. Bioelectron. 2018, 99, 92.

35. Ma, X. X.; Fang, C.; Yan, J. L.; Zhao, Q.; Tu, Y. F.; Talanta 2018, 186, 206. 
36. Zhang, Y. F.; Li, B. X.; Xu, C. L.; Analyst 2010, 135, 1579.

37. Jie, G. F.; Ge, J. J.; Gao, X. S.; Li, C. L.; Biosens. Bioelectron. 2018, 118, 115.
38. Li, Z. J.; Qi, H. L.; Yang, H. Y.; Gao, Q.; Zhang, C. X.; Anal. Methods 2014, 6, 1317.

Submitted: March 21, 2020

Published online: July 17, 2020 